\title{
BIOLOGICAL ACTIVITY OF MUSA ACUMINATA (MUSACEAE) EXTRACTS AGAINST THE MOSQUITO VECTOR; CULEX PIPIENS L. (DIPTERA: CULICIDAE)

\author{
By
}

AHMED S. BREAM, AHMED Z. I. SHEHATA* AND MOHAMED S. M. ZAKI

Department of Zoology, Faculty of Science, Al-Azhar University, Nasr City, Cairo, Egypt ( ${ }^{\star}$ Correspondence:ahmedzeinhom00@gmail.com)

Abstract

The present study evaluated the activity of ethanol $70 \%$, acetone, chloroform and petroleum ether extracts of Musa acuminata leaves against the $3^{\text {rd }}$ instar larvae of the mosquito vector, Culex pipiens (Diptera: Culicidae) which act as a vector of many diseases in Egypt. In addition, the repellent activity of the tested extracts against $C$. pipiens adults was examined. The obtained results revealed that, all tested plant extracts showed a larvicidal activity against the $3^{\text {rd }}$ instar larvae of $C$. pipiens; however, the petroleum ether extract was more effective with $\mathrm{LC}_{50} 571.8 \mathrm{ppm}$ than chloroform, acetone and ethanolic extracts, where the $\mathrm{LC}_{50}$ values recorded 1567.3, 1158.3 and 1034.1ppm; respectively. On the other hand, all tested extracts evoked a variable degree of repellent activity against $C$. pipiens starved females. Also, petroleum ether extract was the most effective extract that exhibited high repellent action as compared with the chloroform, acetone and ethanolic extracts. These results demonstrated that ethanolic, acetone, chloroform and petroleum ether extracts of $M$. acuminata leaves serve as pest control agents, even in their crude form. These results provide an opportunity to develop alternatives to costly organic pesticides with some available cheap plants which are usually safe to the environment and to non-target organisms.

Keys words: Larvicidal, Repellent, C. pipiens, Plant extract, Musa acuminata.

\section{Introduction}

Mosquitoes transmit several public health diseases, such as malaria, filariasis and dengue causing millions of deaths every year (Vatandoost, 2001). In Egypt, Culex pipiens has a wide distribution and is the main vector of Rift Valley fever virus (Meagan et al, 1980; Darwish and Hoogastraal, 1981), Wuchereria bancrofti (Khalil et al, 1930; Gad et al, 1996) and Western Nile virus (El-Bahnasawy et al, 2013). Mmosquitoes immature stages are attractive targets for pesticides as they breed in water and thus easy to deal with them (Johnson and Singh, 2017).

Although chemical pesticides are dealt with $C$. pipiens control for many decades, these chemicals have negative effects on human health and the environment, as well as induce resistance in many mosquito species (Hemingway and Ranson, 2000). Plants are rich source of alternative agents for mosquito's control, because they possess bioactive chemicals, which act as insecticides, oviposition deterrents, repellents, growth inhibitors, juvenile hormone mimics, moult- ing hormones, as well as attractants (Murugan et al, 1996). Also, botanical pesticides offer an advantage over synthetic ones as they are less toxic, less prone to develop resistance and more easily degradable.

\section{Materials and Methods}

Tested mosquitoes: Laboratory of Medical Entomology in the Animal House, Faculty of Science, Al-Azhar University has cultured Culex pipiens mosquito colonies for several generations under controlled temperature and humidity using the standard procedures (Kasap and Demirhan, 1992).

Collection and extraction of plant materials: Musa acuminata was collected in the month of March 2017 from Sharkia Governorate, away from sun rays were left to dry at room temperature $\left(25-30^{\circ} \mathrm{C}\right)$ for 5 to 10 days and pulverized to powder separately in a hammer mill. The extraction was performed using ethanol $70 \%$, acetone, chloroform and petroleum ether solvents. One hundred grams of $M$. acuminata leaves powder for each solvent were extracted separately and filtered five times using $300 \mathrm{ml}$ 
of ethanol, acetone, chloroform and petroleum ether at room temperature. After $24 \mathrm{~h}$., the supernatants were decanted, filtrated through Whatman filter paper (No. 5) and dried in a rotary evaporator at $40{ }^{\circ} \mathrm{C}$ for $2-3$ hours for methanol and 40-60 minutes for other solvents. Dry extracts were weighed and kept at $-4^{\circ} \mathrm{C}$ till using for experiments.

Larvicidal activity: Tested material of the ethanolic extracts was dissolved in $0.1 \mathrm{ml}$ of ethanol 70\%, while those of acetone, chloroform and petroleum ether extracts were dissolved in 2 drops of Tween 80 as emulsifier to facilitate the dissolving oils of tested material in water. Different concentrations of each extract were prepared to detect mortalities.

All tested materials were performed in $250 \mathrm{ml}$. of dechlorinated tap water contained in $300 \mathrm{ml}$ plastic cups. Then, 25 third instar larvae were put immediately into plastic cups contained different concentrations of extracts. Three replicates were usually used for each concentration. All plastic cups were incubated under controlled conditions $\left(27 \pm 2^{\circ} \mathrm{C}, \mathrm{RH} 70 \pm 10 \%\right.$ and $12-12$ light-dark regime). Control larvae received only $0.1 \mathrm{ml}$ of ethanol $70 \%$ or 2 drop of Tween $_{80}$ in $250 \mathrm{ml}$ water. Mortality was recorded every daily (El-Sheikh et al, 2012).

Larval mortality was indicated by a failure to respond to mechanical stimulation (Williams et al, 1986) and estimated using the following equation (Briggs, 1960): larval mortality $\%=\mathrm{A}-\mathrm{B} / \mathrm{A} \times 100$ (where: $\mathrm{A}=$ No. of tested larvae, $B=$ No. of tested pupa).

Pupal mortality percent was estimated using the following equation: Pupal mortality $\%=$ A-B $/ A \times 100$ (where: $A=$ No. of produced pupae, $B=$ No. of emerged adults). Emerging males and females were counted using the following equation: Adult emergence \% $=\mathrm{A} / \mathrm{B} \times 100$ (where: $\mathrm{A}=$ No. of emerged adults, $\mathrm{B}=$ No. of tested pupae). Growth index was estimated by using the equation: Growth index $=a / b$ (where: $A=\%$ of adult emerged and $\mathrm{B}=$ mean development in days)

Repellent activity: Standard cages were used $(20 \times 20 \times 20 \mathrm{~cm})$ to test the repellent ac- tivity of $M$. acuminata extracts. Different weights from each extract were dissolved in $2 \mathrm{ml}$ (ethanol $70 \%$, acetone, chloroform and petroleum ether with a drop of Tween 80 separately) to prepare different concentrations.

The concentration was directly applied onto $5 \times 6 \mathrm{~cm}$ of ventral surface of pigeon after feathers removal from abdomen to evaluate the repellency against $C$. pipiens compared with commercial available repellent DEET (N. N. diethyl-toulamide; Johnson Wax, Egypt) as a positive control agent. After 10 minutes, the treated pigeons were placed in the cages containing $C$. pipiens starved females (5-7d-old) for three hours. Control tests were carried out side by side with treatments using ethanol or water. Each test was repeated three times to get a mean value of repellent activity (El-Sheikh et al, 2012). After treatments, the number of fed and unfed females were calculated according to Abbott (1925): Repellency $\%=[\% \mathrm{~A}-\% \mathrm{~B} /$ 100-\% B] $\times 100$ (where: $A=$ percent of unfed females in treatment and $B=$ percent of unfed females in control.

Statistical analysis: Analysis of data was carried out (lentner et al, 1982). LC L $_{50}$ was calculated using multiple linear regressions (Finney, 1971).

\section{Results}

Larvicidal activity: Larval mortality values were increased linearly with increasing concentrations. The complete larval mortality $(100.0 \%)$ was attained by ethanolic, acetone, chloroform \& petroleum ether extracts at 3500, 3000, 2000 and 1000ppm and the lowest mortality percent $(17.3,28.0,16.0$ \& $20.0 \%$ ) caused by the lowest concentrations (500, 500, $500 \& 300 \mathrm{ppm})$, respectively.

The mean larval duration period was significantly $(\mathrm{P}<0.05)$ prolonged due to ethanolic, acetone and petroleum ether extracts at the higher concentrations as compared with control groups, in the same time. The chloroform extract induced a significant $(\mathrm{P}<0.05)$ shortage in the larval duration values with higher concentrations (1600, 1400, $1200 \& 1000 \mathrm{ppm})$ recorded 5.2, 5.4, $5.7 \&$ 
5.8days, res- pectively, compared with 7.3 days for the Lethal effect of acetone, chloroform and petroleum ether extracts extended to the resulted pupae, as the pupal mortality recorded $36.1 \& 15.2 \%$ at 2500 and 2000 ppm for acetone extract; $33.3,32.8 \& 5.5 \%$ at 1800,1600 and $1400 \mathrm{ppm}$ for chloroform extract and 44.4, 24.5, 24.7, 21.7, 13.9, 16.8 and $16.6 \%$ at $900,800,700,600,500,400$. and $300 \mathrm{ppm}$ for petroleum ether extract, respectively compared with zero pupal mortality in control groups. Ethanolic and chloroform extracts of $M$. acuminata were not significant $(\mathrm{P}>0.05)$ affected the pupal duration, the time taken by pupae to reach adult stage.

Table 1: Effect of ethanolic extract from M. acuminata leaves on some biological aspects of C. pipiens.

\begin{tabular}{|c|c|c|c|c|c|c|c|}
\hline $\begin{array}{c}\text { Conc. } \\
\text { ppm }\end{array}$ & $\begin{array}{c}\text { Larval } \\
\text { mort. (\%) }\end{array}$ & $\begin{array}{c}\text { Larval } \\
\text { Period }\end{array}$ & $\begin{array}{c}\text { Pupal Mort. } \\
(\%)\end{array}$ & $\begin{array}{c}\text { Pupal } \\
\text { Period }\end{array}$ & $\begin{array}{c}\text { Adult } \\
\text { Emergence (\%) }\end{array}$ & $\begin{array}{c}\text { Development } \\
\text { Period }\end{array}$ & $\begin{array}{c}\text { Growth } \\
\text { Index }\end{array}$ \\
\hline 3500 & $100.0 \pm 0.0$ & --- & --- & --- & --- & --- & -- \\
\hline 3000 & $90.7 \pm 2.3$ & $7.1 \pm 0.2^{\mathrm{d}}$ & $0.0 \pm 0.0$ & $3.4 \pm 0.1^{\mathrm{a}}$ & $100.0 \pm 0.0$ & $10.5 \pm 0.3^{\mathrm{c}}$ & 9.5 \\
\hline 2500 & $78.7 \pm 4.6$ & $6.7 \pm 0.3^{\mathrm{c}}$ & $0.0 \pm 0.0$ & $2.8 \pm 0.2^{\mathrm{a}}$ & $100.0 \pm 0.0$ & $9.5 \pm 0.4^{\mathrm{a}}$ & 10.5 \\
\hline 2000 & $65.3 \pm 2.3$ & $6.6 \pm 0.3^{\mathrm{c}}$ & $0.0 \pm 0.0$ & $2.6 \pm 0.4^{\mathrm{a}}$ & $100.0 \pm 0.0$ & $9.2 \pm 0.6^{\mathrm{a}}$ & 10.9 \\
\hline 1500 & $48.0 \pm 6.9$ & $6.5 \pm 0.3^{\mathrm{c}}$ & $0.0 \pm 0.0$ & $2.5 \pm 0.2^{\mathrm{a}}$ & $100.0 \pm 0.0$ & $9.0 \pm 0.5^{\mathrm{a}}$ & 11.1 \\
\hline 1000 & $34.7 \pm 4.6$ & $6.4 \pm 0.2^{\mathrm{b}}$ & $0.0 \pm 0.0$ & $2.4 \pm 0.1^{\mathrm{a}}$ & $100.0 \pm 0.0$ & $8.8 \pm 0.4^{\mathrm{a}}$ & 11.4 \\
\hline 500 & $17.3 \pm 2.3$ & $6.2 \pm 0.1^{\mathrm{a}}$ & $0.0 \pm 0.0$ & $2.4 \pm 0.1^{\mathrm{a}}$ & $100.0 \pm 0.0$ & $8.6 \pm 0.3^{\mathrm{a}}$ & 11.7 \\
\hline Control & $2.7 \pm 2.3$ & $5.6 \pm 0.2^{\mathrm{a}}$ & $0.0 \pm 0.0$ & $2.8 \pm 0.5^{\mathrm{a}}$ & $100.0 \pm 0.0$ & $8.4 \pm 0.7^{\mathrm{a}}$ & 11.9 \\
\hline
\end{tabular}

No. of tested larvae $=25$ per one replicate; Conc. $=$ Concentration; $\mathrm{ppm}=$ particle per million; $\mathrm{SD}=$ standard deviation; mort $=$ mortality; $\mathrm{a}=$ non-significant $(\mathrm{P}>0.05) ; \mathrm{b}=$ significant $(\mathrm{P}<0.05) ; \mathrm{c}=$ highly significant $(\mathrm{P}<0.01) ; \mathrm{d}=$ very highly significant $(\mathrm{P}<0.001)$. Means followed by the same letter are not significantly different.

Table 2: Effect of acetone extract from M. acuminata leaves on some biological aspects of C. pipiens.

\begin{tabular}{|c|c|c|c|c|c|c|c|}
\hline $\begin{array}{c}\text { Conc. } \\
\text { ppm }\end{array}$ & $\begin{array}{c}\text { Larval mort. } \\
(\%)\end{array}$ & $\begin{array}{c}\text { Larval } \\
\text { Period }\end{array}$ & $\begin{array}{c}\text { Pupal Mort. } \\
(\%)\end{array}$ & $\begin{array}{c}\text { Pupal } \\
\text { Period }\end{array}$ & $\begin{array}{c}\text { Adult } \\
\text { Emergence }(\%)\end{array}$ & $\begin{array}{c}\text { Development } \\
\text { Period }\end{array}$ & $\begin{array}{c}\text { Growth } \\
\text { Index }\end{array}$ \\
\hline 3000 & $100.0 \pm 0.0$ & --- & --- & --- & --- & --- & -- \\
\hline 2500 & $88.0 \pm 40.0$ & $7.1 \pm 0.2^{\mathrm{d}}$ & $36.1 \pm 12.7$ & $3.0 \pm 0.1^{\mathrm{c}}$ & $63.9 \pm 12.7$ & $10.1 \pm 0.3^{\mathrm{c}}$ & 6.3 \\
\hline 2000 & $76.0 \pm 40.0$ & $6.4 \pm 0.3^{\mathrm{c}}$ & $15.2 \pm 14.3$ & $2.9 \pm 0.2^{\mathrm{b}}$ & $84.8 \pm 14.3$ & $9.3 \pm 0.5^{\mathrm{b}}$ & 9.1 \\
\hline 1500 & $64.0 \pm 40.0$ & $6.3 \pm 0.1^{\mathrm{b}}$ & $18.8 \pm 4.1$ & $2.7 \pm 0.2^{\mathrm{a}}$ & $81.2 \pm 4.1$ & $9.0 \pm 0.3^{\mathrm{a}}$ & 9.0 \\
\hline 1000 & $45.3 \pm 4.6$ & $6.0 \pm 0.2^{\mathrm{a}}$ & $0.0 \pm 0.0$ & $2.5 \pm 0.2^{\mathrm{a}}$ & $100.0 \pm 0.0$ & $8.5 \pm 0.4^{\mathrm{a}}$ & 11.8 \\
\hline 500 & $28.0 \pm 4.0$ & $5.9 \pm 0.1^{\mathrm{a}}$ & $0.0 \pm 0.0$ & $2.3 \pm 0.1^{\mathrm{a}}$ & $100.0 \pm 0.0$ & $8.2 \pm 0.2^{\mathrm{a}}$ & 12.2 \\
\hline Control & $8.0 \pm 6.9$ & $5.6 \pm 0.2^{\mathrm{a}}$ & $0.0 \pm 0.0$ & $3.0 \pm 0.2^{\mathrm{a}}$ & $100.0 \pm 0.0$ & $8.6 \pm 0.4^{\mathrm{a}}$ & 11.6 \\
\hline
\end{tabular}

Table 3: Effect of chloroform extract from M. acuminata leaves on some biological aspects of C. pipiens.

\begin{tabular}{|c|c|c|c|c|c|c|c|}
\hline $\begin{array}{c}\text { Conc. } \\
\text { ppm }\end{array}$ & $\begin{array}{c}\text { Larval mort. } \\
(\%)\end{array}$ & $\begin{array}{c}\text { Larval } \\
\text { Period }\end{array}$ & $\begin{array}{c}\text { Pupal Mort. } \\
(\%)\end{array}$ & $\begin{array}{c}\text { Pupal } \\
\text { Period }\end{array}$ & $\begin{array}{c}\text { Adult } \\
\text { Emergence }(\%)\end{array}$ & $\begin{array}{c}\text { Development } \\
\text { Period }\end{array}$ & $\begin{array}{c}\text { Growth } \\
\text { Index }\end{array}$ \\
\hline 2000 & $100.0 \pm 0.0$ & --- & --- & --- & --- & --- & --- \\
\hline 1800 & $93.3 \pm 2.3$ & $5.3 \pm 0.0$ & $33.3 \pm 28.9$ & $2.3 \pm 0.2^{\mathrm{a}}$ & $66.7 \pm 28.9$ & $7.6 \pm 0.2^{\mathrm{b}}$ & 8.9 \\
\hline 1600 & $84.0 \pm 4.0$ & $5.2 \pm 1.0^{\mathrm{b}}$ & $32.8 \pm 7.5$ & $2.4 \pm 0.2^{\mathrm{a}}$ & $50.5 \pm 22.4$ & $7.6 \pm 1.2^{\mathrm{b}}$ & 6.6 \\
\hline 1400 & $72.0 \pm 4.0$ & $5.4 \pm 0.4^{\mathrm{b}}$ & $5.5 \pm 9.6$ & $2.6 \pm 0.3^{\mathrm{a}}$ & $94.5 \pm 9.6$ & $8.0 \pm 0.7^{\mathrm{b}}$ & 11.8 \\
\hline 1200 & $62.7 \pm 2.3$ & $5.7 \pm 0.4^{\mathrm{b}}$ & $0.0 \pm 0.0$ & $2.6 \pm 0.3^{\mathrm{a}}$ & $100.0 \pm 0.0$ & $8.3 \pm 0.7^{\mathrm{b}}$ & 12.5 \\
\hline 1000 & $50.7 \pm 4.6$ & $5.8 \pm 0.4^{\mathrm{b}}$ & $0.0 \pm 0.0$ & $2.8 \pm 0.1^{\mathrm{a}}$ & $100.0 \pm 0.0$ & $8.6 \pm 0.5^{\mathrm{a}}$ & 11.6 \\
\hline 800 & $36.0 \pm 4.0$ & $6.4 \pm 1.0^{\mathrm{a}}$ & $0.0 \pm 0.0$ & $3.1 \pm 0.2^{\mathrm{a}}$ & $100.0 \pm 0.0$ & $9.5 \pm 1.2^{\mathrm{a}}$ & 10.5 \\
\hline 500 & $16.0 \pm 4.0$ & $7.0 \pm 0.6^{\mathrm{a}}$ & $0.0 \pm 0.0$ & $3.3 \pm 0.6^{\mathrm{a}}$ & $100.0 \pm 0.0$ & $10.3 \pm 1.2^{\mathrm{a}}$ & 9.7 \\
\hline Control & $5.3 \pm 4.6$ & $7.3 \pm 1.2^{\mathrm{a}}$ & $0.0 \pm 0.0$ & $2.0 \pm 0.1^{\mathrm{a}}$ & $100.0 \pm 0.0$ & $9.3 \pm 1.3^{\mathrm{a}}$ & 10.8 \\
\hline
\end{tabular}

Table 4: Effect of petroleum ether extract from M. acuminata leaves on some biological aspects of $C$. pipiens.

\begin{tabular}{|c|c|c|c|c|c|c|c|}
\hline $\begin{array}{c}\text { Conc. } \\
\text { ppm }\end{array}$ & $\begin{array}{c}\text { Larval mort. } \\
(\%)\end{array}$ & $\begin{array}{c}\text { Larval } \\
\text { Period }\end{array}$ & $\begin{array}{c}\text { Pupal Mort. } \\
(\%)\end{array}$ & $\begin{array}{c}\text { Pupal } \\
\text { Period }\end{array}$ & $\begin{array}{c}\text { Adult } \\
\text { Emergence }(\%)\end{array}$ & $\begin{array}{c}\text { Development } \\
\text { Period }\end{array}$ & $\begin{array}{c}\text { Growth } \\
\text { Index }\end{array}$ \\
\hline 1000 & $100.0 \pm 0.0$ & --- & --- & --- & --- & --- & --- \\
\hline 900 & $90.7 \pm 2.3$ & $7.0 \pm .0 .0$ & $44.4 \pm 9.6$ & $4.0 \pm 0.0$ & $55.5 \pm 9.6$ & $11.0 \pm 0.0$ & 5.0 \\
\hline 800 & $80.0 \pm 6.9$ & $6.7 \pm 0.1^{\mathrm{c}}$ & $24.5 \pm 4.3$ & $3.5 \pm 0.2^{\mathrm{d}}$ & $75.5 \pm 4.3$ & $10.2 \pm 0.3^{\mathrm{d}}$ & 7.4 \\
\hline 700 & $60.0 \pm 8.0$ & $6.0 \pm 0.6^{\mathrm{a}}$ & $24.7 \pm 11.2$ & $3.2 \pm 0.1^{\mathrm{b}}$ & $75.3 \pm 11.2$ & $9.2 \pm 0.7^{\mathrm{a}}$ & 8.2 \\
\hline 600 & $50.7 \pm 6.1$ & $6.3 \pm 0.1^{\mathrm{a}}$ & $21.7 \pm 5.31$ & $3.0 \pm 0.1^{\mathrm{a}}$ & $78.3 \pm 5.3$ & $9.3 \pm 0.1^{\mathrm{a}}$ & 8.4 \\
\hline 500 & $41.3 \pm 8.3$ & $6.1 \pm 0.1^{\mathrm{a}}$ & $13.9 \pm 8.2$ & $2.9 \pm 0.2^{\mathrm{a}}$ & $86.0 \pm 8.1$ & $9.0 \pm 0.2^{\mathrm{a}}$ & 9.6 \\
\hline 400 & $30.7 \pm 12.2$ & $6.07 \pm 0.1^{\mathrm{a}}$ & $16.8 \pm 7.3$ & $2.8 \pm 0.0^{\mathrm{a}}$ & $83.3 \pm 7.2$ & $8.9 \pm 0.1^{\mathrm{a}}$ & 9.4 \\
\hline 300 & $20.0 \pm 10.6$ & $6.03 \pm 0.6^{\mathrm{a}}$ & $16.6 \pm 2.1$ & $2.6 \pm 0.1^{\mathrm{b}}$ & $83.3 \pm 2.1$ & $8.6 \pm 0.7^{\mathrm{a}}$ & 9.7 \\
\hline Control & $2.7 \pm 1.6$ & $5.5 \pm 0.1^{\mathrm{a}}$ & 00.0 & $2.9 \pm 0.1^{\mathrm{a}}$ & $100.0 \pm 0.0$ & $8.4 \pm 0.2^{\mathrm{a}}$ & 11.9 \\
\hline
\end{tabular}


Table 4: Effect of petroleum ether extract from M. acuminata leaves on some biological aspects of C. pipiens.

\begin{tabular}{|c|c|c|c|c|c|c|c|}
\hline $\begin{array}{c}\text { Conc. } \\
\text { ppm }\end{array}$ & $\begin{array}{c}\text { Larval mort. } \\
(\%)\end{array}$ & $\begin{array}{l}\text { Larval } \\
\text { Period }\end{array}$ & $\begin{array}{l}\text { Pupal Mort. } \\
(\%)\end{array}$ & $\begin{array}{l}\text { Pupal } \\
\text { Period }\end{array}$ & $\begin{array}{c}\text { Adult } \\
\text { Emergence }(\%)\end{array}$ & $\begin{array}{l}\text { Development } \\
\text { Period }\end{array}$ & $\begin{array}{l}\text { Growth } \\
\text { Index }\end{array}$ \\
\hline 1000 & $100.0 \pm 0.0$ & --- & --- & --- & --- & --- & --- \\
\hline 900 & $90.7 \pm 2.3$ & $7.0 \pm .0 .0$ & $44.4 \pm 9.6$ & $4.0 \pm 0.0$ & $55.5 \pm 9.6$ & $11.0 \pm 0.0$ & 5.0 \\
\hline 800 & $80.0 \pm 6.9$ & $6.7 \pm 0.1^{\mathrm{c}}$ & $24.5 \pm 4.3$ & $3.5 \pm 0.2^{\mathrm{d}}$ & $75.5 \pm 4.3$ & $10.2 \pm 0.3^{\mathrm{d}}$ & 7.4 \\
\hline 700 & $60.0 \pm 8.0$ & $6.0 \pm 0.6^{\mathrm{a}}$ & $24.7 \pm 11.2$ & $3.2 \pm 0.1^{b}$ & $75.3 \pm 11.2$ & $9.2 \pm 0.7^{\mathrm{a}}$ & 8.2 \\
\hline 600 & $50.7 \pm 6.1$ & $6.3 \pm 0.1^{\mathrm{a}}$ & $21.7 \pm 5.31$ & $3.0 \pm 0.1^{\mathrm{a}}$ & $78.3 \pm 5.3$ & $9.3 \pm 0.1^{\mathrm{a}}$ & 8.4 \\
\hline 500 & $41.3 \pm 8.3$ & $6.1 \pm 0.1^{\mathrm{a}}$ & $13.9 \pm 8.2$ & $2.9 \pm 0.2^{\mathrm{a}}$ & $86.0 \pm 8.1$ & $9.0 \pm 0.2^{\mathrm{a}}$ & 9.6 \\
\hline 400 & $30.7 \pm 12.2$ & $6.07 \pm 0.1^{\mathrm{a}}$ & $16.8 \pm 7.3$ & $2.8 \pm 0.0^{\mathrm{a}}$ & $83.3 \pm 7.2$ & $8.9 \pm 0.1^{\mathrm{a}}$ & 9.4 \\
\hline 300 & $20.0 \pm 10.6$ & $6.03 \pm 0.6^{\mathrm{a}}$ & $16.6 \pm 2.1$ & $2.6 \pm 0.1^{b}$ & $83.3 \pm 2.1$ & $8.6 \pm 0.7^{a}$ & 9.7 \\
\hline Control & $2.7 \pm 1.6$ & $5.5 \pm 0.1^{\mathrm{a}}$ & 00.0 & $2.9 \pm 0.1^{\mathrm{a}}$ & $100.0 \pm 0.0$ & $8.4 \pm 0.2^{\mathrm{a}}$ & 11.9 \\
\hline
\end{tabular}

Table 5: Relative efficiency of tested M. acuminata leaves extracts against larvae of $C$. pipiens.

\begin{tabular}{|c|c|c|c|}
\hline Extract & $\mathrm{LC}_{50}(\mathrm{ppm})$ & \multicolumn{1}{|c|}{ Slope (b) } & $\mathrm{R}^{2}$ \\
\hline Ethanol 70\% & 1567.3 & 0.0279 & 0.9923 \\
\hline Acetone & 1158.3 & 0.0286 & 0.9892 \\
\hline Chloroform & 1034.1 & 0.0564 & 0.9898 \\
\hline Petroleum ether & 571.8 & 0.1173 & 0.9911 \\
\hline
\end{tabular}

Table 6: Repellent activity of tested $M$. acuminata leaves extracts against $C$. pipiens starved females.

\begin{tabular}{|c|c|c|c|c|c|c|c|}
\hline \multirow{2}{*}{ Extracts } & \multirow{2}{*}{$\begin{array}{c}\text { Dose } \\
\left(\mathrm{mg} / \mathrm{cm}^{2}\right)\end{array}$} & \multirow{2}{*}{$\begin{array}{l}\text { No. of tested } \\
\text { females }\end{array}$} & \multicolumn{2}{|c|}{ Fed Females } & \multicolumn{2}{|c|}{ Unfed Females } & \multirow{2}{*}{$\begin{array}{c}\text { Repellency } \\
(\%)\end{array}$} \\
\hline & & & No. & $\%$ & No. & $\%$ & \\
\hline \multirow{3}{*}{$\begin{array}{c}\text { Ethanol } \\
70 \%\end{array}$} & 3.33 & 49 & 12 & 24.5 & 37 & 75.5 & 74.5 \\
\hline & 1.67 & 55 & 16 & 29.1 & 39 & 70.7 & 69.5 \\
\hline & 0.83 & 67 & 22 & 32.8 & 45 & 67.2 & 65.9 \\
\hline \multirow{3}{*}{ Acetone } & 3.33 & 47 & 9 & 19.1 & 38 & 80.9 & 79.0 \\
\hline & 1.67 & 51 & 14 & 27.5 & 37 & 72.5 & 69.8 \\
\hline & 0.83 & 48 & 15 & 31.1 & 33 & 68.7 & 65.6 \\
\hline \multirow{3}{*}{ Chloroform } & 3.33 & 55 & 9 & 16.4 & 46 & 83.6 & 82.8 \\
\hline & 1.67 & 41 & 10 & 24.4 & 31 & 75.6 & 74.5 \\
\hline & 0.83 & 49 & 15 & 30.6 & 34 & 69.4 & 68.0 \\
\hline \multirow{3}{*}{ Pet. ether } & 3.33 & 63 & 6 & 9.5 & 57 & 90.5 & 90.0 \\
\hline & 1.67 & 48 & 8 & 16.7 & 40 & 83.3 & 82.4 \\
\hline & 0.83 & 52 & 11 & 21.2 & 41 & 78.8 & 77.6 \\
\hline DEET & 1.8 & 58 & 0 & 0.0 & 58 & 100.0 & 100.0 \\
\hline Control & 0.0 & 53 & 51 & 96.2 & 2 & 3.8 & 0.0 \\
\hline
\end{tabular}

But, the pupal duration was significantly $(\mathrm{P}<0.05)$ shortened by acetone extract; 3.0 \& 2.9 days at 2500 and $2000 \mathrm{ppm}$ compared with 3.0days for control group (Tab. 2) and significantly $(\mathrm{P}<0.05)$ prolonged by petroleum ether extract; pupal duration was $3.5 \&$ 3.2 days at 800 and $700 \mathrm{ppm}$, respectively, compared with 2.9days for control group.

The reduction in adult emergence percent was observed due to tested acetone, chloroform and petroleum ether extracts, petroleum ether extracts recorded 55.5, 75.5, 75.3, $78.3,86.0,83.3 \& 83.3 \%$ adult emergence at 900, 800, 700, 600, 500, 400 and 300ppm, respectively, compared with complete adult emergence in the untreated group. Also, a retarded effect on growth of larvae, pupae and adult $C$. pipiens was induced by all extracts used especially with petroleum ether extract, which reduced growth index value from 11.9 in control group to 9.7 at lowest concentration (300ppm) and 8.2, 7.4, 5.0 at the highest concentrations $(700,800 \&$ 900ppm), respectively (Tab. 4).

Thus, it was obvious that, the toxicity values of the tested ethanol $70 \%$, acetone, chloroform and petroleum ether extracts of $M$. acuminata leaves based on $\mathrm{LC}_{50}$ values (Tab. 5; Fig. 1) could be arranged in a descending order as follows: Petroleum ether extract $>$ Chloroform extract $>$ Acetone extract $>$ Ethanolic extract.

Repellent activity of tested plant extracts on Culex pipiens adults: The ethanolic, acetone, chloroform and petroleum ether extracts of $M$. acuminata leaves gave a variable degree of repellency. Potent repellency $(90.0 \%)$ attained by petroleum ether extract 
at $3.33 \mathrm{mg} / \mathrm{cm}^{2}$ through the $3 \mathrm{~h}$ post treatment, the ethanolic extract evoked 74.5, 69.5 and $65.9 \%$ protection at $3.33,1.67 \& 0.83$ $\mathrm{mg} / \mathrm{cm}^{2}$. Acetone and chloroform extracts exhibited 79.0, 69.8, 65.6 \& 82.8, 74.5, $68.0 \%$ repellency action, respectively, within the $3 \mathrm{~h}$ post treatment. In addition, $82.4 \&$ $77.6 \%$ repellency achieved by petroleum ether extract at 1.67 and $0.83 \mathrm{mg} / \mathrm{cm}^{2}$, compared with $100.0 \%$ repellency for DEET at a dose of $1.8 \mathrm{mg} / \mathrm{cm}^{2}$ (Tab. 6).

\section{Discussion}

The vector control by synthetic pesticides faced a threat due to the development of resistance to chemical insecticides (Liu et al, 2006). Moreover, this is highly indicated in Egypt with the reemerged Aedes aegypti (Heikal et al, 2011; Shoukry et al, 2012) and the introduced dengue fever (El Bahnasawy et al, 2011a; Morsy, 2018) as well as introduction of Anopheles vector (El-Bahnasawy et al, 2011b) and the imported malignant malaria (El-Bahnasawy et al, 2010) Thus, there is an urgent need to develop new materials for controlling mosquitoes in an environmentally safe way. Plant extracts have been suggested as alternative sources for insect control, because some are selective, biodegrade to nontoxic products and have few effects on non-target organisms and the environment (Singh and Upadhyay, 1993; Isman, 2006; Pavela, 2007). Musa acuminata, belongs to Musaceae family is known to be eco-friendly and isn't toxic to vertebrates. Moreover, it is clearly proved that crude or partially purified plant extracts are less expensive and highly efficacious for the control of Culex pipiens rather than the purified compounds or extracts (Jang et al, 2002; Cavalcanti et al, 2004). The present results offered an opportunity for developing alternatives to rather expensive and environmentally hazardous organic insecticides.

In the present study, toxicity of $M$. acuminata extracts against $3^{\text {rd }}$ instar larvae of $C$. pipiens was varied according to solvent used in extraction and concentration of the extract. The larval mortality percent was in- creased by increasing extract concentration for all plant extracts tested. Generally, the present results indicated that, the petroleum ether extract was more effective against $3^{\text {rd }}$ instar larvae of $C$. pipiens than those of chloroform, acetone and ethanolic extracts. These results were in consistent with the previously mentioned suggestions of (Maurya et $a l, 2009)$. Several studies concerned with the effect of several medicinal plant extracts on different mosquito's species were performed by many authors worldwide (Abdel-Sattar et $a l, 2014$. The effect of tested plant extracts on larval mortality of $C$. pipiens agreed with of Vahitha et al. (2002) for leaf extracts of Pavonia zeylanica and Acacia ferruginea on the late third instar larvae of $C$. quinquefasciatus, LC $_{50}$ values recorded 2214.7 \& 5362.6ppm. Prabakar and jebanesan, (2004) used extracts from five species of Cucurbitacious plants, Momordica charantia, Trichosanthes anguina, Luffa acutangula, Benincasa cerifera and Citrullus vulgaris against the late third larval age of $C$. quinquefasciatus. $\mathrm{LC}_{50}$ values after $24 \mathrm{hr}$ were $465.85,567.81,839.81,1189.30 \& 1636.04$ ppm. Moreover, Nathan et al. (2005) reported that azadirachtin was most potent in all experiments against the malaria vector, $A$. stephensi L. and produced almost $100 \%$ larval mortality at $1 \mathrm{ppm}$ concentration. Coria et al. (2008) used extracts from Melia azedarach on $A$. aegypti, and Maurya et al. (2009) used petroleum ether extract from leaves of a widely grown medicinal plant, Ocimum basilicum, against $A$. stephensi and C. quinquefasciatus and reported that the petroleum ether extract from leaves of $O$. basilicum was most effective against the larvae of both mosquitoes than other extracts with $\mathrm{LC}_{50}$ of $8.29,4.57 ; 87.68,47.25 \mathrm{ppm}$ and $\mathrm{LC}_{90}$ values of $10.06,6.06 ; 129.32$, $65.58 \mathrm{ppm}$ against $A$. stephensi and $C$. quinquefasciatus reswpectively, after $24 \& 48 \mathrm{hr}$ of treatment and Madhua et al. (2010) used Curcuma aromatica rhizomes extracts on $C$. quinquefasciatus larvae. The efficacy of petroleum ether extract seemed to be effective 
with $\mathrm{LC}_{50} \& \mathrm{LC}_{90}$ values of 11.4 and 18.0 ppm. This went with Sakthivadivel et al. (2014) who found that aqueous fruit extract of Wrightia tinctoria exhibited highest larvicidal activity against $C$. quinquefasciatus followed by aqueous leaf extract with $\mathrm{LC}_{50}$ values of $0.17 \%$ and $0.09 \% ; 0.21 \% \& 0.11 \%$ after 24 and 48hr. Samuel et al. (2014) reported that Ipomoea cairica and Ageratina adenophora extracts were effective against third instar larvae of $C$. quinquefasciatus caused $77-100 \%$ mortality at $48 \mathrm{hr}$. Also, Asiry et al. (2017) used ethanolic leaf extracts from four plants, Citrullus colocynthis, Artemisia annua, Pergularia tomentosa and Rhanterium epapposum selected from Hail region, northern Saudi Arabia, against the larval stages of Ae. aegypti. The ethanolic extracts of $R$. epapposum and $A$. annua were more toxic to the $4^{\text {th }}$ instar larvae of $A e$. aegypti compared to the other two plants. Nasir et al. (2017) used essential oils of some medicinal plants against Ae. albopictus, Ginger was more effective with lowest $\mathrm{LC}_{50}$ values after $8 \& 16 \mathrm{hr}$ followed by peppermint, basil, Eucalyptus and Neem. Basil was efficacious after 24 and $48 \mathrm{~h}$.

In the present study, ethanolic and petroleum ether extracts extended the larval and pupal durations. Acetone extract shortened the pupal duration and chloroform extract shortened the larval duration. These results agreed with Jeyabalan et al. (2003) using methanol extract of Pelargonium citrosa leaf against A. stephensi larvae, Nathan et al. (2005) using Azadirachta indica extract against A. stephensi larvae, Nathan et al. (2006) using methanolic extracts of leaves and seeds from chinaberry tree, Melia azedarach against $A$. stephensi larvae, Sharma et al. (2006a; b) using petroleum ether extract of Artemisia annua against A. stephensi and C. quinquefasciatus larvae. Similar observation was reported by Coria et al. (2008) using ethanolic extract of Melia azedarach leaves on Ae. aegypti larvae and Juliene et al. (2009) using Moringa oleifera lectin against Ae. aegypti larvae.
In the present study, the decrease in the percentage of adult emergence of the mosquito vector, $C$. pipiens due to treatment with the tested plant extracts was similar to the results obtained previously by Assar and El- Sobky (2003) using water extracts of Artimisia Monosperma against $C$. pipiens larvae, El- Bokl (2003) using Azadirachta indica extract against $C$. pipiens larvae, Nathan et al. (2006) used methanolic extracts of leaves and seeds of Melia azedarach against A. stephensi larvae, Sharma et al., (2006a; b) used petroleum ether extract of Artemisia annua against $A$. stephensi and $C$. quinquefasciatus larvae, Wiesman and Chapagain, (2006) used one fraction obtained from the silica gel column chromatography of the methanol extract against Aedes aegypti mosquito larvae. Also, Asiry et al. (2017) used ethanolic leaf extracts from four plants, Citrullus colocynthis (bitter apple), Artemisia annua (sweet wormwood), Pergularia tomentosa (Fattaka) and Rhan-terium epapposum (Arfaj) against the larval stages of Ae. aegypti and Nasir et al. (2017) used essential oils of some medicinal plants against Ae. albopictus.

In the present study, the growth index of C. pipiens was affected by the present plant extracts tested. It decreased as the concentration of the extract increased. Retardation in growth was induced by different solvents. Such results were in agreement with earlier studies using different plant extracts against some dipteran species by Jeyabalan et al., (2003) using Pelargonium citrosa leaf extracts on A. stephensi, Nathan et al., (2006) using Melia azedarach on A. stephensi, Sharma et al., (2006 b) sing Artemisia annua extract against C. autnauetesctetus, Bream et al. (2010) using Echinochloa stagninum extracts against $C$. pipiens, El-Sheikh et al. (2012) using methanolic extract of Tribulus terrestris L. (Zygophyllaceae) against the malarial vector, A. arabiensis and Fouda et al. (2017) using L. camara (leaves and stems) extracts against the house fly, Musca domestica. 
In the present study, all doses of plant extracts used in the present study exhibited repellent activity against the starved female adults of $C$. pipiens. The repellent activity was solvent and dose dependent. The results indicate that, petroleum ether extraction of $M$. acuminata was more effective in exhibiting the repellent action against the mosquito tested as compared with chloroform, acetone and ethanolic extract. Many plant extracts and essential oils manifest repellent activity against different mosquito species and the present results were in accordance with such results obtained by Govere et al. (2000) using extracts of fever tea (Lippia javanica), rose geranium (Pelargonium reniforme) and lemon grass (Cymbopogon excavatus) against $A$. arabiensis, Kim et al. (2002) used ethanol extract of fruits from Foeniculum vulgarea against hungry Aedes aegypti females, Choi et al. (2002) tested the essential oils of Eulcalyptus globulus, Lavender officinalis, Rosemarinus officinalis and Thymus vulgaris against $C$. pipiens, Jeyabalan et al. (2003) using methanol extracts of Pelargonium citrosa against $A$. stephensi, Tuetun et al. (2004) using extracts of Apium graveolens seeds against Ae. aegypti, Yang et al. (2004) using methanol extracts from twenty- three aromatic medicinal plant species against $A e$. aegypti female, Prajapati et al. (2005) using essential oils extracted from ten medicinal plants against $A$. stephensi and $C$. quinquefasciatus, Choochote et al. (2007) using repellent activity of selected essential oils from ten plant species against Ae. aegypti and Chio and Yang (2008) using Neem tree (Azadirachta indica) oil against Ae. albopictus. Besides, El- Sheikh et al. (2012) used methanolic extract of Tribulus terrestris (leaves \& seeds) against $A$. arabiensis and found that the seeds extract was more effective repellent (100\%) against the mosquito compared with leaves extract $(79.5 \%)$ at dose $1.0 \& 2.0 \mathrm{mg} / \mathrm{cm}^{2}$, and Adhikari and Chandra (2014) who found that petroleum ether leaf extract of Swietenia mahagoni against $A$. stephensi showed repellency up to
$2 \mathrm{hr}$ after treatment. El-Hela et al. (2013) screened 110 Egyptian medicinal herbs and plants to evaluate their larvicidal activity against Ae. aegypti. They reported that the highly effective ones were Coronilla scorpioides, Forsskaolea tenacissima, Crataegus sinaica, Pistacia khinjuk and Loranthus acacia that exhibited the highest potency calculated as 22.53 $\pm 2.01,23.85 \pm 2.07,28.17 \pm$ $2.06,31.60 \pm 2.93 \& 39.73 \pm 4.58 \mathrm{mg} \%$ aqueous extracts and $18.53 \pm 1.95,18.8 \pm 1.67$, $20.17 \pm 1.85,23.28 \pm 2.7 \& 28.48 \pm 3.9 \mathrm{mg} \%$ methanol ones respectively.

\section{Conclusion}

Searching for the new natural adulticides and larvicides become an urgent demand due to the health hazards accompanying the use of synthetic ones and the strict need of such environmental friend agents to decline many the health disasters caused by insectborne infectious diseases.

Musa acuminata extracts used considered as new promising controlling and repellent agents for the mosquito vector, $C$. pipiens. Further, in near future we need to initiate studies leading to find the bioactive compounds in M. acuminata which may responsible for larvicidal and repellent activity.

\section{References}

Abbott, WS, 1925: A method for computing the effectiveness of an insecticide. J. Econ. Entomol. 18:265-77.

Abdel-Sattar, E, Zaitoon, A, El Sayed, AM, Bakhashwain, AA, 2014: Evaluation of some medicinal plants in controlling Culex pipiens. J. Egypt. Soc. Parasitol. 44, 3:771-8

Adhikari, U, Chandra, G, 2014: Larvicidal, smoke toxicity, repellency and adult emergence inhibition effects of leaf extracts of Swietenia mahagoni Linnaeus against Anopheles stephensi Liston (Diptera: Culicidae). Asian Pac. J. Trop. Dis. 4, 1:279-83.

Asiry, KA, Hassan, SSM, Ibrahim, NA, AlKhuraiji, IA, Kehial, MA, et al, 2017: Larvicidal efficacy of ethanolic leaf extracts of four selected local plants from hail region, northern Saudi Arabia, against the dengue fever vector, Aedes aegypti (L.) under laboratory conditions. Int. J. Mosq. Res. 4, 3:81-7. 
Assar, AA, El- Sobky, MM, 2003: Biological and histopathlogical studies of some plant extracts on larvae of $C$. pipiens (Diptera: Culicidae). J. Egypt. Soc. Parasitol. 33, 1:189-200.

Bream, AS, El-Sheikh, TM, Fouda, MA, Hassan, MI, 2010: Larvicidal and repellent activity of extracts derived from aquatic plant Echinochloa stagninum against Culex pipiens. Tunis. J. Plant Protec. 5:107-23.

Briggs, JN, 1960: Reduction of adult house fly emergence by the effective Bacillus sp. on the development of immature forms. J. Insect pathology. 2: 418-32.

Cavalcanti, ES, Morais, SM, Lima, MA, Santana, EW, 2004: Larvicidal activity of essential oils from Brazilian plants against Ae. aegypti L. Mem. Inst. Oswaldo. Cruz. 99, 5: 541-4.

Chio, EH, Yang, EC, 2008: A bioassay for natural insect repellents. J. Asia Pac. Entomol. 11: 225-7.

Choi, WS, Park, BS, Ku, SK, Lee, SE, 2002: Repellent activities of essential oils and monoterpenes against $C$. pipiens pallens. J. Am. Mosq. Cont. Assoc. 18, 4:348-51.

Choochote, W, Chaithong, U, Kamsuk, K, Jitpakdi, A, Tippawangkosol, $P$, et al, 2007: Repellent activity of selected essential oils against Aedes aegypti. Fitoterapia 78:359-64.

Coria, C, Almiron, W, Valladares, G, Carpinella, C, Luduen a, F, et al, 2008: Larvicide and oviposition deterrent effects of fruit and leaf extracts from Melia azedarach L. on Aedes aegypti (L.) (Diptera: Culicidae). Bioresou. Technol. 99:3066-70.

Darwish, M, Hoogstraal, H, 1981: Arboviruses infesting human and lower animals in Egypt. A review of thirty years of research. J. Egypt. Pub. Hlth. Assoc. 56:1-112.

El-Bahnasawy, MM, Dabbous, HKh, Morsy, TA, 2010: Imported malaria as a threat to Egypt. J. Egypt. Soc. Parasitol. 40, 3:773-87.

El-Bahnasawy, MM, Khalil, HHM, Morsy, A TA, Morsy, TA, 2011a: Threat of dengue fever and dengue haemorrhagic fever to Egypt from travelers. J. Egypt. Soc. Parasitol. 41, 2: 289306.

El-Bahnasawy, MM, Saleh, NMK, Khalil, M F, Morsy, TA, 2011b: The impact of three anopheline mosquito species in Toshka, on the introduction of chloroquine resistant $P$. falciparum to Egypt. J. Egypt. Soc. Parasitol. 41, 3:557-92.
El-Bahnasawy, MM, Khater, MMKh, Morsy, TA, 2013: The mosquito borne west Nile virus infection: Is it threating to Egypt or a neglected endemic disease? J. Egypt. Soc. Parasitol. 43, 1: 87-102.

El-Bokl, MM, 2003: Latent toxicity of azadirachtin treatment on $C$. pipiens (Diptera: Culicidae). J. Egypt. Acad. Soc. Environ. Develop. 3, 1:63-74.

El-Hela, AA, Abdel-Hady, NM, Dawoud, GT M, Hamed, AM, Morsy, TA, 2013: Phenolic content, antioxidant potential and Aedes aegyptii eco-logical friend larvicidal activity of some selected Egyptian Plants. J. Egypt. Soc. Parasitol. 43, 1:215-34

El-Sheikh, TMY, Bosly, HMA, Shalaby, N, 2012: Insecticidal and repellent activities of methanolic extract of Tribulus terrestris L. (Zygophyllaceae) against the malarial vector Anopheles arabiensis (Diptera: Culicidae). Egypt. Acad. J. Biol. Sci. 5, 2:13-22.

Finney, DJ, 1971: Probit Analysis. Third Edition. Cambridge University Press.

Fouda, MA, Hassan, MI, Shehata, AZ, Hasaballah, AI, Gad, ME, 2017: Larvicidal and Antifeedant Activities of Different Extracts from Leaves and Stems of Lantana camara (Verbenaceae) Against the Housefly, Musca domestica L. Egypt. Acad. J. Biolog. Sci., 9(1): 85-98.

Gad, AM, Hammad, RE, Farid, HA, 1996: Uptake and development of Wucheria bancrofti in C. pipiens L. and Ae. caspius Pallas. J. Egypt. Soc. Parasitol., 26(2): 305-14.

Govere, TA, Durrheim, DN, Du, TN, Hunt, R H, Coetzee, M, 2000: Local plants as repellents against $A$. arabiensis, in Mpumalanga Province, South Africa. Cent. Afr. J. Med. 46, 8: 213-6.

Heikal, OM, El-Bahnasawy, MM, Morsy, AT, Khalil, HH, 2011: Aedes aegypti re-emerging in Egypt: A review and what should be done? J. Egypt. Soc. Parasitol. 41, 3:801-14.

Hemingway, J, Ranson, H, 2000: Insecticide resistance in insect vectors of human disease. Ann. Rev. Entomol. 45:371-91.

Isman, MB, 2006: Botanical insecticides, deterrent, and repellent in modern agriculture and increasingly regulated world. Ann. Rev. Entomol. 51:45-66.

Jang, YS, Baek, BR, Yang, YC, Kim, MK, Lee, HS, 2002: Larvicidal activity of leguminous seeds and grains against Ae. aegypti and $C$. 
pipiens pallens. J. Am. Mosq. Control Assoc. 18, 3:210-3.

Jeyabalan, D, Arul, N, Thangamathi, P, 2003: Studies on effects of Pelargonium citrosa leaf extracts on malarial vector, A. stephensi Liston. Bioresour. Technol., 89(2): 185-189.

Johnson, A. D. and Singh, A. 2017: Larvicidal activity and biochemical effects of Apigenin against Filarial Vector Culex quinquefasciatus. Int. J. Life. Sci. Scienti. Res., 3(5): 1315-21.

Kasap, M, Demirhan, 1992: The effect of various larval foods on the rate of adult emergence and fecundity of mosquitoes. Turkiye Parazitol. Dergisi. 161:87-97.

Khalil, M, Malawani, A, Hilmi, IS, 1930: The transmission of Bancroftian filariasis in Egypt. J. Egypt. Med. Assoc., 15:315-32.

Kim, DH, Kim, SI, Chang, KS, Ahn, YJ, 2002: Repellent activity of constituents identified in Foeniculum vulgare fruit against Ae. aegypti (Diptera: Culicidae). J. Agric. Food Chem. 50, 24:6993-6.

Lentner, C, Lentner, C, Wink, A, 1982: Students t- distribution tables. In: Geigy scientific Tables Vol. 2. International Medical and Pharmaceutical information, Ciba-Geigy Limited, Basal, Switzerland.

Liu, N, Xu, Q, Zhu, F, Zhang, L, 2006: Pyrethroid resistance in mosquitoes. Insect Sci. 13: 159-66.

Madhu, SK, Shaukath, AK, Vijayan, VA, 2010: Efficacy of bioactive compounds from Curcuma aromatica against mosquito larvae. Acta Trop. 113:7-11.

Maurya, P, Sharma, p, Mohan, L, Batabyal L, Srivastava, CN, 2009: Evaluation of the toxicity of different phytoextracts of Ocimum basilicum against Anopheles stephensi and Culex quinquefasciatus. J. Asia-Pacific Entomol. 12: 113-5.

Meagan, JM, Khalil, GM, Hoogstraal, H, Adham, FK, 1980: Experimental transmission and field isolation studies implicating C. pipiens as a vector of Rift Valley virus in Egypt. Am. J. Trop. Med. Hyg. 80:1405-10.

Morsy, TA, 2018: Aedes aegypti and dengue virus infections. J. Egypt. Soc. Parasitol. 48, 1: 183-96.

Murugan, TS, Babu, R, Jeyabalan, D, Kumar, SN, Sivaramkrishnan, S, 1996: Antipupational effect of Neem oil and neem seed kernel extract against mosquito larvae of A. stephensi (Liston). J. Entomol. Res. 20:137-9.
Nasir, S, Nasir, I, Asrar, M, Debboun, M, 2017: Larvicidal and pupicidal action of medicinal plant extracts against dengue mosquito Aedes albopictus (Skuse) (Diptera: Culicidae). Indian J. Anim. Res. 51, 1:155-8.

Nathan, SS, Kalaivani, K, Murugan, k, 2005: Effects of Neem limonoids on the malaria vector A. stephensi Liston (Diptera: Culicidae). Acta Trop. 96, 1: 47-55.

Nathan, SS, Savitha, G, George, DK, Narmadha, A, Suganya, L, et al, 2006: Efficacy of Melia azedarach $\mathrm{L}$. extract on the malarial vector A. stephensi Liston (Diptera: Culicidae). Bioresour Technol. 79:1316-23.

Pavela, R, 2007: Larvicidal effects of various Euro-Asiatic plants against $C$. quinquefasciatus Say larvae (Diptera: Culicidae). Parasitol. Res. 36:821-3.

Prabakar, K, Jebanesan, A, 2004: Larvicidal efficacy of some Cucurbitacious plant leaf extracts against $C$. quinquefasciatus (Say). Bioresour. Technol. 95, 1:113-4.

Prajapati, V, Tripathi, AK, Aggarwal, KK, Khanuja, SP, 2005: Insecticidal, repellent and oviposition-deterrent activity of selected essential oils against $A$. stephensi, Ae. aegypti and $C$. quinquefasciatus. Bioresour. Technol. 96, 16: 1749-57.

Sakthivadivel, M, Gunasekaran, P, Annapoorani, JT, Samraj, DA, Arivoli, S, et al, 2014: Larvicidal activity of Wrightia tinctoria R. BR. (Apocynaceae) fruit and leaf extracts against the filarial vector Culex quinquefasciatus Say (Diptera: Culicidae). Asian Pac. J. Trop. Dis. 4, 1: 373-7.

Samuel, L, Lalrotluanga, Muthukumaran, $\mathbf{R}$ B, Gurusubramanian, G, Senthilkumar, N, 2014: Larvicidal activity of Ipomoea cairica (L.) Sweet, and Ageratina adenophora (Spreng.) King \& H. Rob. plant extracts against arboviral and filarial vector, Culex quinquefasciatus Say (Diptera: Culicidae). Exp. Parasitol. 141:112-21.

Sharma, P, Mohan, L, Srivastava, CN, 2006a: Phytoextract-induced developmental deformities in malaria vector. Bioresour. Technol., 97:1599604.

Sharma, P, Mohan, L, Srivastava, CN, 2006b: Growth Inhibitory Nature of Artemisia annua Extract against Culex autnauetesctetus (Say). J. Asia-Pacific Entomol. 9, 4:389-95.

Shoukry, NM, Elwan, MA, Morsy, TA, 2012: Aedes aegypti (Linnaeus) re-emerging in southern Egypt. J. Egypt. Soc. Parasitol. 42, 1:41-50. 
Singh, G, Upadhyay, RK, 1993: Essential oils a potent source of natural pesticides. J. Sci. Ind. Res. 52: 676-83.

Tuetun, B, Choochote, W, Rattanachanpichai, E, Chaithong, U, Jitpakdi, A, et al, 2004: Mosquito repellency of the seeds of celery (Apium graveolens L.). Ann. Trop. Med. Parasitol. 98, 4:407-17.

Vahitha, R, Venkatachalam, MR, Murugan, K, Jebanesan, A, 2002: Larvicidal efficacy of Pavonia zeylanica L. and Acacia ferruginea D. C. against $C$. quinquefasciatus Say. Bioresour. Technol. 82, 2:203-04.

Vatandoost, HVM, 2001: Larvicidal activity of Neem extract; Azadirachta indica against mosquito larvae in Iran. Pestology 25:69-72.
Wiesman, Z, Chapagain, P, 2006: Larvicidal activity of saponin containing extracts and fractions of fruit mesocarp of Balanites aegyptiaca. Fitoterapia 77:420-24.

Williams, KA, Green, DWJ, Pascoe, D, Gower, DE, 1986: The acute toxicity of cadmium to different larval stages of Chrionomus riparius (Diptera: Chironomidae) and its ecological significance for pollution regulation. J. Sci. Unvi. Tokushima 22:25-31.

Yang, YC, Lee, EH, Lee, HS, Lee, DK, Ahn, YG 2004: Repellency of aromatic medicinal plant extracts and a steam distillate to Ae. aegypti. J. Am. Mosq. Control Assoc. 20, 2:146-49.

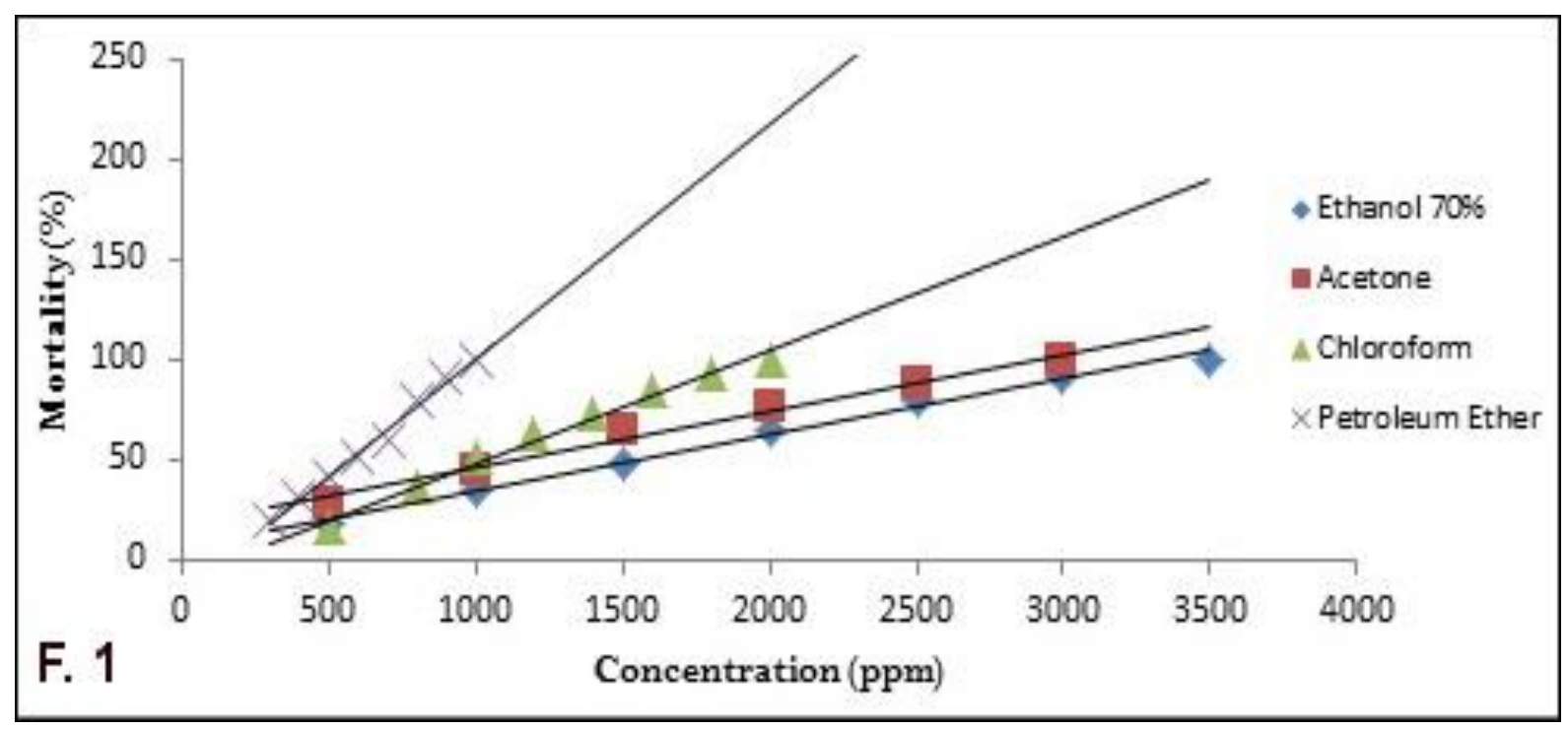

Fig. 1: Regression line of $C$. pipiens larval mortality as induced by tested M. acuminata extracts. 